\title{
Mucoepidermoid carcinoma of buccal mucosa
}

\author{
Nalam Sai Gautam, ${ }^{1}$ Ramya Shanmuga Atmakuri, ${ }^{2}$ Sumit Majumdar, ${ }^{2}$ Divya Uppala ${ }^{2}$
}

'Department of Pedodontics, GITAM Dental College, Vishakhapatnam, Andhra Pradesh, India

${ }^{2}$ Department of Oral Pathology, GITAM Dental College, Visakhapatnam, Andhra Pradesh, India

\section{Correspondence to}

Dr Nalam Sai Gautam, gautham316@rediffmail.com

Accepted 5 October 2014

\section{DESCRIPTION}

Mucoepidermoid carcinoma (MEC) is considered the most common malignant salivary gland tumour. MEC constitutes $3-10 \%$ of all tumours of major salivary glands and $10-15 \%$ of tumours of minor salivary glands. ${ }^{1}$

It occurs most commonly in the parotid gland, with minor salivary glands of the palate being the second most common site. ${ }^{2}$ Within the oral cavity, MEC often resembles a mucocele. MECs have a female predilection and are decidedly uncommon in the first decade of life. ${ }^{3}$ We report a case with unusual clinical findings.

A 13-year-old boy presented with a 3-month history of painless swelling on the right buccal mucosa near the commissure of his lower lip (figure 1). On examination, the swelling was well defined, smooth, fluctuant, firm and non-tender on palpation.

A provisional diagnosis of mucocele was established. An excisional biopsy was performed. The histopathology revealed proliferation of nests of tumour cells containing intermediate and epidermoid cells in the connective tissue. A part of the section showed eosinophilic mucous pooled areas lined with goblet cells (figures 2 and 3 ).

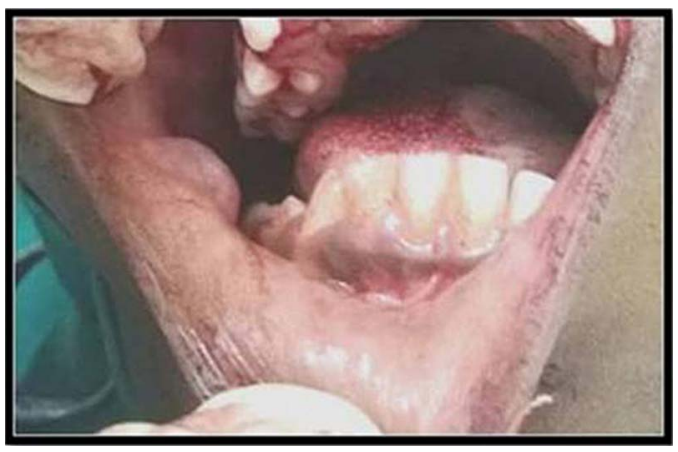

Figure 1 Intraoral photograph.

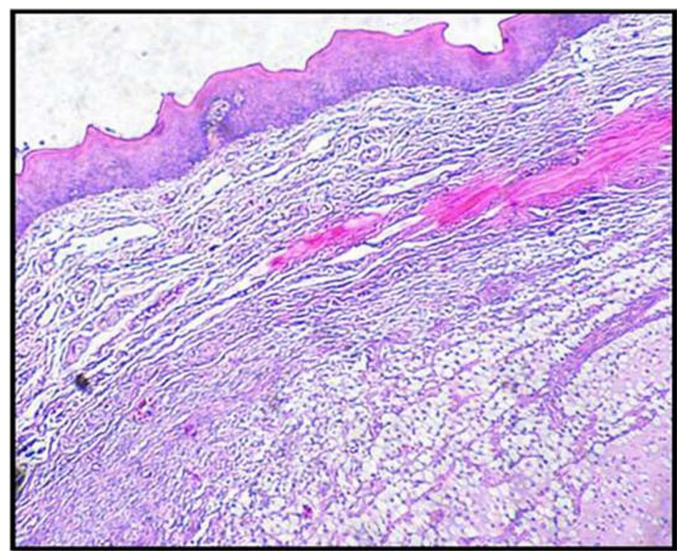

Figure 2 Overlying normal epithelium with cystic spaces (H\&E stain $-\times 4$ view).

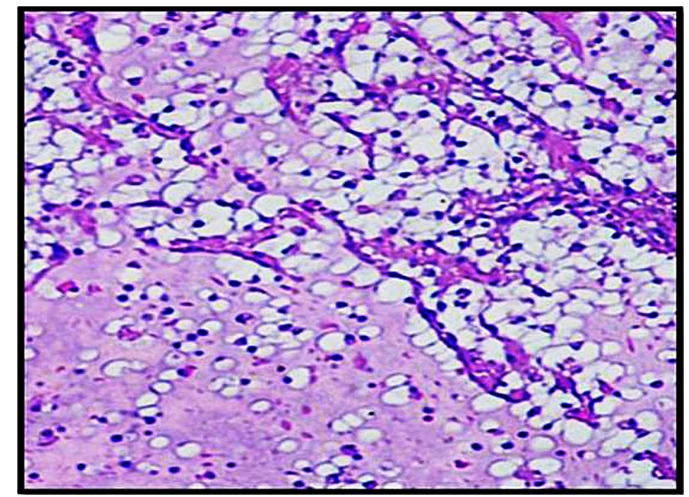

Figure 3 Clear cells and intermediate cells arranged in sheets (H\&E stain $-\times 40$ view).

The overall features were in favour of low grade mucoepidermoid carcinoma of minor salivary gland.

It is worth noting that swellings in the buccal mucosa and labial mucosal resembling a mucocele could turn out to be MEC, as was the case in this report. Patients with these types of swellings must be considered cautiously and a multidisciplinary approach can lead to successful treatment.

\section{Learning points}

- Although the site of occurrence of mucoepidermoid carcinoma (MEC) may be rare, there should be an open eye on MEC as a differential diagnosis while diagnosing a mucocele.

- Although MECs occur in children for the most part, rare conditions of occurrence in different age groups should also be considered.

- This report highlights the importance of careful histopathological examination of apparently innocuous lesions.

Contributors All the authors are involved in diagnosis of this present case and also in writing the manuscript.

\section{Competing interests None.}

Patient consent Obtained.

Provenance and peer review Not commissioned; externally peer reviewed.

\section{REFERENCES}

1 Jensen JL. Idiopathic diseases. In: Ellis GL, Auclair PL, Gnepp DR, eds. Surgical pathology of the salivary glands. Philadelphia, PA: WB Saunders, 1991:60-82.

2 Ritwik P, Cordell KG, Brannon RB. Minor salivary gland mucoepidermoid carcinoma in children and adolescents: a case series and review of the literature. J Med Case Rep 2012;6:182.

3 Asuquo ME, Nwagbara VI, Umana AN, et al. Giant MEC in parotid gland: a case report and review of literature. J Clin Exp Oncol 2013;2:1. 
Copyright 2014 BMJ Publishing Group. All rights reserved. For permission to reuse any of this content visit http://group.bmj.com/group/rights-licensing/permissions.

BMJ Case Report Fellows may re-use this article for personal use and teaching without any further permission.

Become a Fellow of BMJ Case Reports today and you can:

- Submit as many cases as you like

- Enjoy fast sympathetic peer review and rapid publication of accepted articles

- Access all the published articles

- Re-use any of the published material for personal use and teaching without further permission

For information on Institutional Fellowships contact consortiasales@bmjgroup.com

Visit casereports.bmj.com for more articles like this and to become a Fellow 